DOI:

\title{
Slaughter and carcass quality characteristics of Chios $\times$ Tahirova crossbred lambs under intensive, traditional and organic production systems*
}

\author{
Omur KOCAK, Bulent EKIZ, Hulya YALCINTAN, Alper YILMAZ \\ İstanbul University, Veterinary Faculty, Department of Animal Breeding and Husbandry, İstanbul, Turkey.
}

\begin{abstract}
Summary: The aim was to investigate the slaughter and carcass quality characteristics and carcass measurements of Chios $\times$ Tahirova crossbred lambs raised under intensive, traditional and organic production systems in Afyon. Intensive lambs were weaned at $71 \mathrm{~d}$ of age and then finished with commercial concentrates in the sheepfold until slaughter. Traditional lambs were kept with their mothers at sheepfold until 108 days old, and then they were brought out to pasture with their mothers in the daytime. Organic lambs were kept in sheepfold with their mothers until 106 days of age and then they were grazed in organic pasture with their mother until slaughter. Mixture of organically produced straw, barley and sunflower meal was supplied to organic lambs at nights. Lambs reached to $30 \mathrm{~kg}$ live weight were slaughtered. Mean finishing duration was $72 \mathrm{~d}, 79 \mathrm{~d}$ and $92 \mathrm{~d}$ in traditional, intensive and organic lambs, respectively $(\mathrm{P}<0.05)$. Lambs of three production systems had similar carcass weight, percentages of dressing and carcass joints. Lean ratio of the long leg in traditional system was higher than the other production systems $(\mathrm{P}<0.05)$. Organic lambs had lower percentages of omental and mesenterial fat and subcutaneous fat in long leg compared with intensive lambs $(\mathrm{P}<0.05)$. As a conclusion, traditional production system has better results when compared to organic and intensive production systems in terms of carcass quality parameters. Organic lambs had lower percentages of subcutaneous fat and omental and mesenteric fat than lambs of intensive system.
\end{abstract}

Key words: Carcass quality, fatness, lamb production, production system.

\section{Entansif, geleneksel ve organik üretim sistemlerinde yetiştirilen Sakız $\times$ Tahirova melezi kuzuların kesim ve karkas kalitesi özellikleri}

Özet: Çalışmada, Afyon ilindeki özel bir işletmede entansif, geleneksel ve organik üretim sistemlerinde yetiştirilen Sakız $\times$ Tahirova melezi kuzuların kesim ve karkas kalitesi özelliklerinin ve çeşitli karkas ölçülerinin belirlenmesi amaçlanmıştır. Entansif kuzular 71 günlük yaşta sütten kesilmişler ve kesime kadar ağıl içerisinde besiye alınmışlardır. Geleneksel yetiştirilen kuzular 108 günlük yaşa kadar ağıl içerisinde anaları ile birlikte tutulmuşlar, 108 günlük yaştan sonra ise anaları ile meraya çıkarılmışlardır. 106 günlük yaşa kadar anaları ile beraber ağıl içerisinde barındırılan organik kuzular, bu yaştan sonra gündüzleri anaları ile birlikte organik meraya çıkarılmışlardır. Organik kuzulara ayrıca akşamları organik olarak üretilmiş kuru ot, arpa ve ayçiçeği küspesinden oluşan yem karması verilmiştir. $30 \mathrm{~kg}$ canlı ağırlığa ulaşan kuzular kesime sevk edilmişlerdir. Çalışmada geleneksel, entansif ve organik kuzuların ortalama besi süreleri sırasıyla 72,79 ve 92 gün olarak tespit edilmiştir $(\mathrm{P}<0.05)$. Farklı üretim sistemlerinde yer alan kuzuların karkas ağırlığı, karkas randımanı ve karkas parçalarının oranları bakımından benzer ortalama değerlere sahip oldukları belirlenmiştir. Uzun buttaki et oranı bakımından geleneksel üretim sisteminde yetiştirilen kuzuların diğer üretim sistemlerine kıyasla daha yüksek ortalamaya sahip olduğu tespit edilmiştir $(\mathrm{P}<0.05)$. Entansif kuzular ile kıyaslandığında organik kuzuların omental ve mezenterik yağ ve uzun butta derialtı yağ oranı bakımından daha düşük ortalamalara sahip oldukları belirlenmiştir $(\mathrm{P}<0.05)$. Sonuç olarak, karkas kalitesi parametreleri bakımından entansif ve organik üretim sistemleri ile kıyaslandığında geleneksel üretim sisteminin daha iyi sonuçlar verdiği görülmüştür.

Anahtar sözcükler: Karkas kalitesi, kuzu üretimi, üretim sistemi, yağlılık.

\section{Introduction}

In Turkey, 27.5 million head sheep are bred (15) and the $24.2 \%$ of red meat production is provided from sheep production (15). According to economical conditions of the breeders, consumer's preferences, field- grazing land resources and production goal of the enterprises (milk, meat, wool, combine), different production systems are preferred in the world. Generally sheep production is performed with traditional techniques in small family type farms in Turkey (18). In traditional

The present study was supported by the Research Fund of Istanbul University (Project No: 2002 and UDP-14325). 
production system, natural resources such as grazing lands and stubble are used during the most of the year and quite few additional feed is given, for the aim of providing nutritional needs of animals. Male lambs are usually fed with their mother's milk and grazed until reaching slaughter weight. In the winter months, which there are inadequate resource of grazing lands, male lambs are fed in the sheep pen with the mixture of limited amount of roughage and commercial concentrated feed $(12,26)$.

Recently, crisis such as BSE, Foot and Mouth Disease (FMD) and dioxin issues related with animal products made consumers to concern about the food security and thus demand to organic products increased (19). The usage of the antiparasitic and antibiotic drugs for preventive medicine, growth provocating feed supplies and nutrition with genetically modified products is forbidden in organic animal production (1). For this reason, organic labelled animal products are perceived as more secure and healthier by consumers.

The quality of the lamb carcass varies according to breeding system (6). Grazing lambs generally have less fatty carcasses than that of lambs fed concentrates (9). When lambs were slaughtered at similar live weight, carcass weight and dressing percentage of organic lambs were reported lower than lambs of intensive systems (23). Moreover, organic lambs which were slaughtered at similar age with the lambs which were fed intensively have less body weight and dressing percentage (20).This study is a part of the project aiming to determine the finishing performance, slaughter, carcass and meat quality characteristics of lambs under organic, traditional and intensive production systems in order to obtain knowledge for the production system choice to produce high quality lamb meat. In this part of the study, the slaughter and carcass quality characteristics and carcass measurements of Chios $\times$ Tahirova crossbred lambs were investigated comparatively.

\section{Materials and Methods}

The research protocol of the current study was approved by the Ethic Committee of Istanbul University (Approval number: 2007/41). The study was conducted in a private sheep farm where organic and traditional production systems are administered in Afyon. In addition to organic and traditional production systems in the scope of the study, an experimental group was also conducted in which intensive lamb finishing was applied. Crossbred lambs which were research material (1/4 Chios $X 3 / 4$ Tahirova genotype) were chosen between single-male lambs which were born in the end of the December 2008. It was provided that there would not be any significant difference between organic, traditional and intensive production systems according to initial age $(\mathrm{P}=0.752)$ and weights of lambs $(\mathrm{P}=0.872)$.
Intensive production system ( $n=9)$ : Lambs in this group were kept with their mothers in the sheepfold until 71 days old age. During this time, in addition to mother's milk $60 \%$ straw and $40 \%$ commercial concentrated feed mixture was also given to lambs. These lambs were weaned at 71 days old and then were kept in $2.1 \mathrm{~m}^{2}$ per animal for finishing. In the finishing period, mixture of $40 \%$ of straw and $60 \%$ of commercial concentrated feed were given to the lambs ad-libitum.

Traditional production system $(n=10)$ : Traditional lambs suckled their mothers until slaughter age. These lambs were kept until 108 days old with their mothers. The mixtures of $60 \%$ straw and $40 \%$ commercial concentrated feed were given to the traditional lambs in addition to their mother's milk. After $108^{\text {th }}$ day lambs were brought out to pasture with their mothers in the daytime, they got only mother's milk at the night. No straw or concentrated feed were added to nutritional program in this group after 108 days of age.

Organic production system $(n=9)$ : Lambs in organic production system were kept in sheepfold with their mothers until 106 days of age. During this period, the mixture of organically produced straw $(60 \%)$, barley $(28 \%)$ and sunflower meal $(12 \%)$ were supplied to the lambs with free access in addition to their mother's milk. These lambs were grazed in organic pasture with their mother from the age of 106 days old. Lambs and their mothers were placed in different pens in the sheepfold in night time and the mixture of organically produced straw, barley and sunflower meal was supplied to lambs at nights.

The grass samples were taken from 10 different points in the pasture at the beginning of the grazing season and the sampling areas $\left(20 \times 20 \mathrm{~cm}^{2}\right)$ were 50 meters apart from each other. Nutrient compositions of feeds were determined according to the Weende analysis system but neutral detergent fiber (NDF) fraction was determined using the procedure described by Van Soest et al. (24) and acid detergent fiber (ADF) was determined using the method of Goering and Van Soest (17) as adapted for the Ankom200 Fiber Analyzer (Ankom Technology, USA). Chemical composition of the concentrate feed, barley, sunflower meal, straw and pasture used in the current study are given in Table 1.

In the study, target slaughter weight was determined as $30 \mathrm{~kg}$ and in the weekly weightings the lambs which reached to target weight were transported to Istanbul University Veterinary Faculty Experimental Abattoir. Lambs were rested one night in lairage unit $(3.10 \times 3.86$ m) at slaughterhouse and during this time they got free access to water, but access to food wasn't allowed. Slaughter of the lambs was executed by following the standard procedure of the slaughterhouse. Lambs were slaughtered after electrical stunning. Head, skin, feet and internal organs were removed and then carcasses were 
Table 1. Chemical composition of commercial concentrate feed, barley, sunflower meal, straw and pasture used in the study Tablo 1. Araştırmada kullanılan ticari konsantre yem, arpa, ayçiçeği küspesi, kuru ot ve meranın kimyasal bileşimi

\begin{tabular}{lccccc}
\hline Chemical composition & $\begin{array}{c}\text { Commercial } \\
\text { concentrate feed }^{\mathrm{D}}\end{array}$ & Barley & Sunflower meal & Straw & Pasture \\
\hline Dry matter, \% & 90.45 & 90.26 & 93.70 & 94.20 & 29.80 \\
Crude protein, \% & 17.44 & 10.68 & 19.75 & 2.44 & 12.39 \\
Ether extract, \% & 6.86 & 1.42 & 1.12 & 1.29 & 1.85 \\
Crude cellulose, \% & 9.60 & 5.50 & 38.89 & 40.80 & 37.10 \\
Ash, \% & 6.47 & 2.35 & 5.67 & 6.15 & 12.20 \\
$\mathrm{NDF}^{\mathrm{A}}, \%$ & 31.47 & 20.10 & 41.80 & 73.68 & 44.12 \\
$\mathrm{ADF}^{\mathrm{B}}, \%$ & 14.86 & 7.50 & 21.10 & 54.26 & 37.56 \\
${\text { Metabolizable energy }(\mathrm{MJ} / \mathrm{kg} \mathrm{DM})^{\mathrm{C}}}^{\mathrm{A}}$ & 10.47 & 11.81 & 8.62 & 4.94 & 6.28 \\
\hline
\end{tabular}

A NDF: Neutral Detergent Fibre.

${ }^{\text {B }}$ ADF: Acid Detergent Fibre.

${ }^{\mathrm{C}}$ Calculated values.

D Per kg of concentrate feed supplied the following mineral/vitamin premix: vitamin A, 6000 IU; vitamin D3, 750 IU; tocopherol acetate, $15 \mathrm{mg}$; vitamin B1, $1 \mathrm{mg}$; vitamin B2, $4 \mathrm{mg}$; vitamin B6, $2 \mathrm{mg}$; vitamin B12, $0.01 \mathrm{mg}$; niacin, $20 \mathrm{mg}$; pantothenic acid, 10 $\mathrm{mg}$; folic acid, $0.1 \mathrm{mg}$; Fe, $50 \mathrm{mg}$; Zn, $50 \mathrm{mg}$; I, $0.4 \mathrm{mg}$; Co, $0.3 \mathrm{mg}$; Se, $0.3 \mathrm{mg}$.

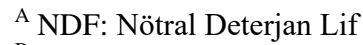

${ }^{B}$ ADF: Asit Deterjan Lif

${ }^{\mathrm{C}}$ Hesaplanan Değerler

D Konsantre yemde kg başına bulunan vitamin/mineral karışımı: vitamin A, 6000 IU; vitamin D3, 750 IU; tocopherol acetate, 15 mg; vitamin B1, $1 \mathrm{mg}$; vitamin B2, $4 \mathrm{mg}$; vitamin B6, $2 \mathrm{mg}$; vitamin B12, $0.01 \mathrm{mg}$; niacin, $20 \mathrm{mg}$; pantothenic acid, $10 \mathrm{mg}$; folic acid, 0.1 $\mathrm{mg}$; Fe, $50 \mathrm{mg}$; Zn, $50 \mathrm{mg}$; I, $0.4 \mathrm{mg}$; Co, $0.3 \mathrm{mg}$; Se, $0.3 \mathrm{mg}$.

obtained. Kidneys and the pelvic fat were left on the carcass. All carcasses' weight was recorded after kept in $4^{\circ} \mathrm{C}$ cold storage for 24 hours. In the study, dressing percentage was calculated according to both slaughter weight and empty body weight.

Body length, back length, long leg length, hind limb length, carcass width, chest dept, chest circumference, buttock width, buttock circumference, carcass length, internal carcass length and internal chest dept were measured according to method reported by Fisher and de Boer (16). Carcass compactness, buttock compactness and chest roundness index were also calculated (13, 22).

After carcass measurements were taken, right half carcasses were dissected into 5 joints as; neck, shoulder, flank, ribs and long leg, with the dissection method as defined by Colomer- Rocher et al. (8) and the weight of each joint were recorded.

The percentage of the carcass joints were calculated according to half carcass weight. In order to determine the physical composition of the carcasses, dissection [lean, bone, subcutaneous fat, intermuscular fat and other tissues (vessels, tendons, nerves etc.)] of the right long leg was performed with the method as stated by Fisher and de Boer (16).

One way ANOVA and Duncan's multiple range tests (21) in SPSS 13.0 program packet were applied in order to compare the slaughtering and carcass quality of the lambs in the groups of intensive, traditional and organic production systems.

\section{Results}

In the scope of the study, finishing period was started for the lambs in the different production systems at similar age and at about $17 \mathrm{~kg}$ body weight. However lambs of the traditional system reached to the target final weight of $30 \mathrm{~kg}$ earlier than organic lambs (Table 2). In regard to chilled carcass weight, dressing percentage and chilling losses, differences between production systems were not significant $(\mathrm{P}>0.05)$. It was resulted that lambs in organic system have higher lung+trachea percentage and heart percentage when compared to those of other production systems $(\mathrm{P}<0.001)$. Differences between production systems were not significant in regard to percentages of liver and spleen $(\mathrm{P}>0.05)$.

In terms of the carcass measurements except hind limb length, buttock width and buttock circumference, the differences between production systems were not significant $(\mathrm{P}>0.05$, Table 3$)$. It is observed that the hind limb length of the organic lambs was higher than the intensive lambs; and the buttock width and buttock circumference of intensive lambs was higher than the organic lambs $(\mathrm{P}<0.05)$.

Percentages of various carcass joints of the lambs in organic, intensive and traditional systems are given in Table 4. According to the percentages of neck, shoulder, flank, long leg, tail and kidneys, the differences between production systems were not significant (P>0.05). 
Table 2. Means and standard errors (SE) for certain finishing and slaughter characteristics in lambs Tablo 2. Kuzuların bazı besi ve kesim özelliklerine ait ortalamalar ve standart hatalar (SE)

\begin{tabular}{|c|c|c|c|c|c|c|c|}
\hline \multirow[t]{2}{*}{ Characteristics } & \multicolumn{2}{|c|}{$\begin{array}{c}\text { Traditional } \\
\mathrm{n}=10\end{array}$} & \multicolumn{2}{|c|}{$\begin{array}{c}\text { Intensive } \\
n=9\end{array}$} & \multicolumn{2}{|c|}{$\begin{array}{c}\text { Organic } \\
n=9\end{array}$} & \multirow[t]{2}{*}{ P Value } \\
\hline & Mean & SE & Mean & SE & Mean & SE & \\
\hline Initial age, day & 72.10 & 2.31 & 70.44 & 1.73 & 70.00 & 2.12 & NS \\
\hline Initial live weight, $\mathrm{kg}$ & 17.60 & 0.58 & 17.00 & 0.74 & 17.43 & 0.75 & NS \\
\hline Finishing duration, day & $72.00^{\mathrm{b}}$ & 3.00 & $79.00^{\mathrm{ab}}$ & 6.14 & $92.00^{\mathrm{a}}$ & 6.67 & 0.043 \\
\hline Final weight, $\mathrm{kg}$ & 30.74 & 0.30 & 30.84 & 0.41 & 29.47 & 0.55 & NS \\
\hline Chilled carcass weight, $\mathrm{kg}$ & 13.15 & 0.23 & 13.13 & 0.36 & 12.45 & 0.35 & NS \\
\hline Dressing percentage ${ }^{1}, \%$ & 51.60 & 0.35 & 51.55 & 0.55 & 51.30 & 0.63 & NS \\
\hline Dressing percentage ${ }^{2}, \%$ & 45.57 & 0.24 & 45.00 & 0.80 & 44.17 & 0.96 & NS \\
\hline Chilling loss, $\%$ & 3.09 & 0.17 & 3.40 & 0.13 & 3.61 & 0.13 & NS \\
\hline Head percentage, $\%$ & 6.98 & 0.12 & 6.67 & 0.14 & 7.13 & 0.14 & NS \\
\hline Feet percentage, $\%$ & 3.06 & 0.04 & 2.97 & 0.05 & 2.98 & 0.06 & NS \\
\hline Lungs and trachea percentage, $\%$ & $1.93^{\mathrm{b}}$ & 0.05 & $1.73^{\mathrm{c}}$ & 0.04 & $2.23^{\mathrm{a}}$ & 0.01 & $<0.001$ \\
\hline Heart percentage, $\%$ & $0.56^{\mathrm{b}}$ & 0.01 & $0.54^{\mathrm{b}}$ & 0.01 & $0.65^{\mathrm{a}}$ & 0.01 & $<0.001$ \\
\hline Liver percentage, $\%$ & 2.19 & 0.05 & 2.09 & 0.07 & 2.09 & 0.09 & NS \\
\hline Spleen percentage, $\%$ & 0.29 & 0.04 & 0.26 & 0.01 & 0.38 & 0.05 & NS \\
\hline
\end{tabular}

${ }^{a, b}$ : Differences between the means of production systems carrying various letters in the same line are significant.

${ }^{1}$ : Dressing percentage based on empty body weight, ${ }^{2}$ : Dressing percentage based on slaughter weight.

${ }^{\mathrm{a}, \mathrm{b}}$ : Aynı satırda farklı harf taşıyan üretim sistemlerine ait ortalama değerler arasındaki farklılıklar önemlidir.

${ }^{1}$ : Boş vücut ağırlığına göre karkas randımanı, ${ }^{2}$ : Kesim ağırlığına göre karkas randımanı.

Table 3. Means and standard errors (SE) for certain carcass measurements in lambs

Tablo 3. Kuzuların bazı karkas ölçülerine ait ortalamalar ve standart hatalar (SE)

\begin{tabular}{|c|c|c|c|c|c|c|c|}
\hline \multirow{2}{*}{ Characteristics } & \multicolumn{2}{|c|}{$\begin{array}{c}\text { Traditional } \\
\mathrm{n}=10\end{array}$} & \multicolumn{2}{|c|}{$\begin{array}{c}\text { Intensive } \\
\mathrm{n}=9\end{array}$} & \multicolumn{2}{|c|}{$\begin{array}{c}\text { Organic } \\
\mathrm{n}=9\end{array}$} & \multirow[t]{2}{*}{ P Value } \\
\hline & Mean & SE & Mean & SE & Mean & SE & \\
\hline Body length, $\mathrm{cm}$ & 55.44 & 0.36 & 54.26 & 0.90 & 54.82 & 0.52 & NS \\
\hline Back length, cm & 57.71 & 0.65 & 57.02 & 1.31 & 59.70 & 0.74 & NS \\
\hline Long leg length, $\mathrm{cm}$ & 37.35 & 0.33 & 36.78 & 0.66 & 38.14 & 0.56 & NS \\
\hline Hind limb length, $\mathrm{cm}$ & $27.14^{\mathrm{ab}}$ & 0.35 & $26.26^{\mathrm{b}}$ & 0.40 & $27.91^{\mathrm{a}}$ & 0.51 & 0.039 \\
\hline Carcass width, $\mathrm{cm}$ & 19.14 & 0.29 & 19.52 & 0.49 & 18.44 & 0.47 & NS \\
\hline Chest depth, cm & 27.37 & 0.21 & 26.70 & 0.31 & 27.52 & 0.25 & NS \\
\hline Chest circumference, $\mathrm{cm}$ & 69.30 & 0.62 & 68.33 & 0.41 & 68.80 & 0.31 & NS \\
\hline Buttock width, cm & $19.48^{\mathrm{ab}}$ & 0.15 & $19.81^{\mathrm{a}}$ & 0.25 & $18.97^{\mathrm{b}}$ & 0.18 & 0.019 \\
\hline Buttock circumference, $\mathrm{cm}$ & $55.53^{\mathrm{a}}$ & 0.39 & $55.53^{\mathrm{a}}$ & 0.51 & $53.51^{\mathrm{b}}$ & 0.67 & 0.017 \\
\hline Carcass length, $\mathrm{cm}$ & 68.52 & 0.79 & 68.74 & 1.21 & 70.40 & 0.79 & NS \\
\hline Internal carcass length, $\mathrm{cm}$ & 58.82 & 0.35 & 58.43 & 0.71 & 58.42 & 0.43 & NS \\
\hline Internal chest depth, cm & 19.27 & 0.25 & 18.67 & 0.24 & 19.54 & 0.29 & NS \\
\hline Carcass compactness, $\mathrm{g} / \mathrm{cm}$ & 223.72 & 4.46 & 224.83 & 5.96 & 212.96 & 5.32 & NS \\
\hline Chest roundness index & 0.75 & 0.01 & 0.78 & 0.02 & 0.72 & 0.02 & NS \\
\hline Hind limb compactness, $\mathrm{g} / \mathrm{cm}$ & 77.37 & 2.14 & 79.13 & 2.06 & 72.75 & 2.47 & NS \\
\hline
\end{tabular}

${ }^{a, b}$ : Differences between the means of production systems carrying various letters in the same line are significant.

a, b: Aynı satırda farklı harf taşıyan üretim sistemlerine ait ortalama değerler arasındaki farklılıklar önemlidir. 
Table 4. Means and standard errors (SE) for percentages of carcass joints

Tablo 4. Karkas parçalarının oranlarına ait ortalamalar ve standart hatalar (SE)

\begin{tabular}{lccccccc}
\hline \multirow{2}{*}{ Characteristics } & \multicolumn{2}{c}{ Traditional } & \multicolumn{2}{c}{$\begin{array}{c}\text { Intensive } \\
\mathrm{n}=10\end{array}$} & \multicolumn{2}{c}{$\begin{array}{c}\text { Organic } \\
\mathrm{n}=9\end{array}$} & \multicolumn{2}{c}{ P Value } \\
\cline { 2 - 7 } & Mean & SE & Mean & SE & Mean & SE & \\
\hline Neck, \% & 8.31 & 0.35 & 8.22 & 0.36 & 8.43 & 0.28 & NS \\
Shoulder, \% & 19.90 & 0.12 & 19.42 & 0.25 & 20.23 & 0.32 & NS \\
Flank, \% & 10.07 & 0.31 & 9.83 & 0.29 & 9.89 & 0.27 & NS \\
Ribs, \% & 25.29 & 0.37 & 26.09 & 0.51 & 25.23 & 0.58 & NS \\
Long leg, \% & 33.05 & 0.27 & 32.73 & 0.47 & 33.60 & 0.49 & NS \\
Kidney, \% & 0.74 & 0.03 & 0.76 & 0.03 & 0.78 & 0.03 & NS \\
Tail, \% & 3.25 & 0.21 & 3.58 & 0.38 & 2.54 & 0.41 & NS \\
\hline
\end{tabular}

Table 5. Means and standard errors (SE) for composition of long leg and certain carcass fatness characteristics Tablo 5. Uzun butun bileşimi ve bazı karkas yağlılı̆̆ özelliklerine ait ortalamalar ve standart hatalar (SE)

\begin{tabular}{|c|c|c|c|c|c|c|c|}
\hline \multirow{2}{*}{ Characteristics } & \multicolumn{2}{|c|}{$\begin{array}{c}\text { Traditional } \\
n=10\end{array}$} & \multicolumn{2}{|c|}{$\begin{array}{c}\text { Intensive } \\
n=9\end{array}$} & \multicolumn{2}{|c|}{$\begin{array}{c}\text { Organic } \\
n=9\end{array}$} & \multirow{2}{*}{$P$ Value } \\
\hline & Mean & SE & Mean & SE & Mean & SE & \\
\hline Lean, $\%$ & $62.10^{\mathrm{a}}$ & 0.64 & $59.41^{\mathrm{b}}$ & 0.84 & $60.81^{\mathrm{b}}$ & 0.64 & 0.026 \\
\hline Bone, $\%$ & 18.08 & 0.16 & 18.01 & 0.44 & 18.29 & 0.35 & NS \\
\hline Subcutaneous fat, $\%$ & $8.52^{\mathrm{ab}}$ & 0.56 & $10.45^{\mathrm{a}}$ & 0.99 & $6.85^{\mathrm{b}}$ & 0.08 & 0.015 \\
\hline Intermuscular fat, $\%$ & 4.24 & 0.27 & 4.64 & 0.28 & 4.23 & 0.14 & NS \\
\hline Other tissues $^{\beta}, \%$ & 4.49 & 0.28 & 4.66 & 0.12 & 4.80 & 0.30 & NS \\
\hline Lean/total fat ratio & 5,01 & 0,33 & 4.20 & 0.44 & 5,70 & 0,47 & NS \\
\hline Lean/bone ratio & 3,44 & 0,05 & 3.31 & 0.07 & 3,27 & 0,05 & NS \\
\hline Total fat ratio in long leg, $\%$ & $12.76^{\mathrm{b}}$ & 0.65 & $15.10^{\mathrm{a}}$ & 1.18 & $11.08^{\mathrm{b}}$ & 0.91 & 0.019 \\
\hline Oment. \& mesent. fat, \% & $0.70^{\mathrm{ab}}$ & 0.08 & $0.83^{\mathrm{a}}$ & 0.11 & $0.51^{\mathrm{b}}$ & 0.06 & 0.049 \\
\hline $\mathrm{KKCF}^{\partial}, \%$ & 0.58 & 0.052 & 0.78 & 0.16 & 0.54 & 0.033 & NS \\
\hline
\end{tabular}

${ }_{\mathrm{a}, \mathrm{b}}$ : Differences between the means of production systems carrying various letters in the same line are significant.

${ }^{\beta}$ : Major blood vessels, tendons, larger nerves and lymph nodes.

${ }^{\partial} \mathrm{KKCF}$ : Kidney knob and channel fat.

a, b: Aynı satırda farklı harf taşıyan üretim sistemlerine ait ortalama değerler arasındaki farklılıklar önemlidir.

${ }^{\beta}$ : Büyük kan damarları, tendonlar, geniş sinirler ve lenf nodülleri.

${ }^{\partial} \mathrm{KKCF}$ : Böbrek ve leğen yağı.

Dissection results of the long leg joints and the results of certain carcass fatness parameters are given in Table 5. Lean ratio of the long leg in traditional system is higher than the other production systems $(\mathrm{P}<0.05)$. Subcutaneous fat percentage in long leg and omental and mesenterial fat percentages in organic lambs were less than those of intensive lambs $(\mathrm{P}<0.05)$. In regard to kidney knob and channel fat (KKCF) percentages the differences between the production systems were not significant $(\mathrm{P}>0.05)$.

\section{Discussion and Conclusion}

In the study which is aiming to compare the slaughtering and carcass characteristics of the lambs under organic, traditional and intensive production systems, organic lambs reached to target slaughter weight later than the lambs of traditional production system. Coefficient of variation (CV) value of finishing duration in traditional, intensive and organic groups were 13, 23 and $21 \%$, respectively, which might indicate the similar intra-group variation for this characteristic in all investigated production systems. This difference might be explained by the different nutrition programs among the production systems. Traditional system lambs were kept with their mothers whole day, while organic lambs grazed at pasture with their mothers in daytimes, and were separated at nights. Numerous authors also reported that lambs which consume more mothers' milk were growing faster or reaching to slaughter weight earlier (3, $14,25)$. In the study, the similarity in carcass weight and 
dressing percentage of the lambs in different production systems could be explained by the experimental design of the study, in which lambs were slaughtered on similar live weight. Values obtained for dressing percentage in the current study was comparable with those results of previous studies for lambs slaughtered at about 150 days of age (27) or about $30 \mathrm{~kg}$ live weight $(7,11)$.

The higher percentages of heart, lung and trachea of the organic lambs could be related to the older slaughter age of these lambs than lambs of the other production systems. Ekiz et al. (10) also reported higher lung and trachea percentage for older lambs when lambs were slaughtered at the same live weight.

In the study, the hind limb lengths of the intensive lambs were found shorter when compared to organic lambs. This result may depend on the less time requirement for the intensive lambs to reach to the target slaughter weight. On the other hand, higher mean values for buttock width and buttock circumference in intensive lambs when compared to organic lambs can be explained by the more subcutaneous fat in intensive lambs.

Intensive lambs had higher total fat percentage in long leg compared with lambs grazed at pasture. Supporting this result, Cañeque et al. (4) also found fat percentage in the long leg of intensive lambs higher than the lambs grazed in pasture and they stated that the weak fatness of the pasture lambs was related with low energy intake of these lambs. Ekiz et al. (10), Borton et al. (2) and Cividine et al. (7) also found that fat percentages in the long leg were lower in grazed lambs than intensive lambs. Díaz et al. (9) explained the lower fat percentages in long leg of grazed lambs by more exercising of these lambs.

It is observed that, intensive lambs have more omental and mesenteric fat percentages than organic lambs. The difference between production systems with regard to KKCF percentage was not significant. Development of KKCF in finishing period is occurred later than the development of omental and mesenteric fat (5). In this study since the difference between the groups with regard to omental and mesenteric fat percentage was significant, absence of significant difference for KKCF percentage can be explained by the relatively late development of pelvic and renal fat.

Organic system resulted with lower carcass fatness when compared with intensive system, however organic lambs needed more time to reach the target slaughter weight. Moreover lean percentage in long leg was lower in organic lambs than that of traditional lambs. Intensive lambs had lower lean percentage and higher total fat percentage in long leg compared with lambs of traditional system. When production systems investigated in the study was evaluated with regard to meat and total fat percentage, lambs of traditional system was found as the optimal group.

\section{References}

1. Anonymous (2010): Organik Tarımin Esaslarl ve Uygulanmasina İlişkin Yönetmelik (The regulation on the principles of organic farming and their implementation). Republic of Turkey Ministry of Agriculture and Rural Affairs, No: 27676, Ankara. Available at: http://mevzuat.basbakanlik.gov.tr/Metin.Aspx?MevzuatKo $\mathrm{d}=7.5 .14217 \&$ MevzuatIliski $=0 \&$ sourceXmlSearch $=\operatorname{tar} \% \mathrm{C}$ 4\%B1m. (12.09.2014)

2. Borton RJ, Loerch SC, McClure KE, Wulf DM (2005): Characteristics of lambs fed concentrates or grazed on ryegrass to traditional or heavy slaughter weights. II Wholesale cuts and tissue accretion. J Anim Sci, 83, 13451352.

3. Cañeque V, Velasco S, Díaz M, Pérez C, Huidobro F, Lauzurica S, Manzanares C, González J (2001): Effect of weaning age and slaughter weight on carcass and meat quality of Talaverana breed lambs raised at pasture. Anim Sci, 73, 85-95.

4. Cañeque V, Velasco S, Díaz MT, Ruiz de Huidobro F, Pérez C, Lauzurica S (2003): Use of whole barler with a protein supplement to fatten lambs under different management systems and its effect on meat and carcass quality. Anim Res, 52, 271-285.

5. Carrasco S, Ripoll G, Sanz A, Álvarez-Rodríguez J, Panea B, Revilla R, Joy M (2009): Effect of feeding system on growth and carcass characteristics of Churra Tensina light lambs. Livest Sci, 121, 56-63.

6. Chestnutt DMB (1994): Effect of lamb rate and growth pattern on carcass fat levels. Anim Prod, 58, 77-85.

7. Cividine A, Kompan D, Žgur S (2007): The effect of production system and weaning on lamb carcass traits and meat characteristics of Autochthonous Jezerskoločava breed. Poljoprivreda, 13, 145-149.

8. Colomer-Rocher F, Morand-Fehr P, Kirton AH (1987): Standard methods and procedures for goat carcass evaluation, jointing and tissue separation. Livest Prod Sci, 17, 149-159.

9. Díaz MT, Velasco S, Cañeque V, Lauzurica S, Ruiz de Huidobro F, Pérez C, González J Manzanares C (2002): Use of concentrate or pasture for fattening lambs and its effect on carcass and meat quality. Small Rumin Res, 34, 257-268.

10. Ekiz B, Demirel G, Yilmaz A, Ozcan M, Yalcintan H, Kocak O, Altinel A (2013): Slaughter characteristics, carcass quality and fatty acid composition of lambs under four different production systems. Small Rumin Res, 114, 26-34.

11. Ekiz B, Ekiz EE, Kocak O, Yalcintan H, Yilmaz A (2012): Effect of pre-slaughter management regarding transportation and time in lairage on certain stress parameters, carcass and meat quality characteristics in Kivircik lambs. Meat Sci, 90, 967-976.

12. Ekiz B, Ekiz EE, Yalcintan H, Kocak O, Yilmaz A (2012): Effects of suckling length (45, 75 and 120d) and rearing type on cortisol level, carcass and meat quality characteristics in Kivircik lambs. Meat Sci, 92, 53-61.

13. Ekiz B, Ozcan M, Yilmaz A, Tölü C, Savaş T (2010): Carcass measurements and meat quality characteristics of dairy suckling kids compared to an indigenous genotype. Meat Sci, 85, 245-249. 
14. Ekiz B, Yilmaz A, Ozcan M, Kocak O (2012): Effect of production system on carcass measurement and meat quality of Kivircik lambs. Meat Sci, 90, 465-471.

15. FAO (2014): Food and Agriculture Organization of the United Nations, Available at: http://faostat.fao.org/ site/339/default.aspx. (12.09.2014).

16. Fisher AV, de Boer H (1994): The EAAP standart method of sheep carcass assessment. Carcas measurement and dissection procedures. Report of the EAAP working group on carcass evaluation, in cooperation with the CIHEAM Instituto Agronomico Mediterraneo of Zaragoza and the CEC Directorate General for Agricultute in Brussels. Livest Prod Sci, 38, 149-159.

17. Goering HK, VanSoest PJ (1971): Forage Fiber Analysis. USDAARS Agriculture Handbook No. 379. Washington, DC, USA: Government Printing Office.

18. Gürsoy O (2006): Economics and profitability of sheep and goat production in Turkey under new support regimes and market conditions. Small Rumin Res, 62, 181-191.

19. Kouba M (2003): Quality of organic animal products. Livest Prod Sci, 80, 33-40.

20. Morbidini L, Pollidori P, Sarti DM, Valigi A (2003): Effet of "organic" farming system on carcass quality of Italian Merino heavy lambs. Ital J Anim Sci, 2 (Suppl. 1), 494-496.

21. Özdamar (1999): SPSS ile biyoistatistik, 3. Bask1. Kaan Kitabevi, Eskişehir.

22. Santos VAC, Silva AO, Cardoso JVF, Silvestre AJD, Silva SR, Martins C, Azevedo JMT (2007): Genotype and sex effects on carcass and meat quality of suckling kids protected by the PGI "Cabrito de Barrosa". Meat Sci, 75, 725-736.
23. Soysal D, Cibik R, Aydin C, Ak İ (2011): Comparison of conventional and organic management conditions on growth performance, carcass characteristics and haematological parameters in Karacabey Merino and Kivircik breeds. Trop Anim Health Prod, 43, 817-823.

24. Van Soest PJ, Robertson JB, Lewis BA (1991): Method for dietary fiber, neutral detergent fiber, and nonstarch polysaccharides in relation to animal nutrition. J Dairy Sci, 74, 3583-3597.

25. Velasco S, Cañeque V, Lauzurica S, Pérez C, Huidobro F (2004): Effect of different feeds on meat quality and fatty acid composition of lambs fattened at pasture. Meat Sci, 66, 457-465.

26. Yalçin BC (1986): Sheep and goats in Turkey. FAO Animal Production and Health Paper: 60, Food and Agriculture Organization of the United Nations, Rome.

27. Yılmaz A, Özcan M, Ekiz B, Akgündüz M (2002): Türk Merinosu, Sakız ve Kivirclk ırkları arasindaki melezlemeler ile et veriminin artırılma olanaklarının araştırılması: 2. Kuzuların Besi, Kesim ve Karkas Özellikleri. Turk J Vet Anim Sci, 26, 1333-1340.

Geliş tarihi: 09.12.2014 / Kabul tarihi: 12.05.2015
Address for correspondence: Assoc. Prof. Dr. Omur Kocak, Istanbul University, Veterinary Faculty, Department of Animal Breeding and Husbandry, Avcllar, Istanbul, Turkey, e-mail address: okocak@istanbul.edu.tr 